\section{Rapid action of oestradiol against hydrogen peroxide- induced oxidative stress in cataractous lens epithelium: an in vitro study}

D Gajjar, D Patel, B Alapure, MR Praveen, A Patel, $K$ Johar Sr and AR Vasavada
Department of Molecular Biology, lladevi Cataract and IOL Research Centre, Ahmedabad, Gujarat, India

Correspondence:

AR Vasavada,

Raghudeep Eye Clinic, Iladevi Cataract and IOL Research Centre,

Gurukul Road, Memnagar, Ahmedabad, 380052

Gujarat, India

Tel: + 917927490909 ,

27492303;

Fax: +9179 27411200

E-mail: icirc@

abhayvasavada.com

Received: 27 February 2008 Accepted in revised form: 25 August 2008 Published online: 19 September 2008

The authors have declared that no conflict of interest exists

\begin{abstract}
Purpose To evaluate the short-term protective effects of oestradiol against damages because of oxidative stress in human lens epithelial cells (LECs).

Methods The central zone of human lens epithelium was obtained from the cataract surgery and cultured in MEM culture medium. These cultured LECs were treated with $17 \beta$-oestradiol for varying time intervals from 1 to 5 min followed by treatment with $\mathrm{H}_{2} \mathrm{O}_{2}$ $\left(5 \times 10^{-6} \mathrm{M}\right)$ in the culture medium. Catalase activity was measured to access the oxidative stress levels.

Results LECs exposed to $\mathrm{H}_{2} \mathrm{O}_{2}\left(5 \times 10^{-6} \mathrm{M}\right)$ showed a fourfold increase in catalase activity $(407.03 \pm 89.11 \mathrm{U} / \mu \mathrm{g}$ protein) after $6 \mathrm{~h}$ when compared to cultured unexposed LECs $(97.124 \pm 9.4 \mathrm{U} / \mu \mathrm{g}$ protein). When the cultured LECs were treated with oestradiol $\left(5 \times 10^{-8} \mathrm{M}\right)$ before $\mathrm{H}_{2} \mathrm{O}_{2}$ treatment, the increase in catalase activity was inhibited, whereas simultaneous and post-treatments showed no effect. The catalase activity of LECs pretreated with oestradiol for $1,2,3$, and $5 \mathrm{~min}$ was $259.92 \pm 18.37,200.24 \pm 14.39,140.50 \pm 19.83$, and $110.01 \pm 14.66$, respectively $(P<0.0001)$.

Conclusion Antioxidative enzymes are synthesized in response to the oxidative stress signal. Upon treatment with oestrogen catalase is not synthesized. The pretreatment time of oestrogen required for its antioxidative effect can be seen within $5 \mathrm{~min}$ indicating non-genomic mode of action of oestrogen. Eye (2009) 23, 1456-1463; doi:10.1038/eye.2008.284; published online 19 September 2008
\end{abstract}

Keywords: cataract; $17 \beta$ oestradiol; oxidative stress; catalase; lens epithelial cells (LECs)
Introduction

The first indication of the eye as a target organ for sex steroid hormones emerged from epidemiological studies that indicated an increased incidence of ocular disorders in women. ${ }^{1}$ Various epidemiological studies suggest that women are at a higher risk of developing cataracts than men of the same age group. This risk increases only after menopause, thus leading to the hypothesis that oestrogen is the protective molecule during the reproductive age. As far as the cumulative incidence of cataract is concerned, women are more likely than men to have nuclear cataract. ${ }^{2}$ Prevalence data from the Barbados Eye Study, which had a predominantly black population, demonstrated that cortical and nuclear opacities are more frequent in women than in men. ${ }^{3}$ Other studies on the beneficial effects of oestrogen, such as the Beaver Dam Eye Study and the Salisbury Eye Evaluation Project found protective associations between hormone use and lens nuclear opacity. Weintraub et $a l^{4}$ evaluated hormone replacement therapy and lens opacities in a population of 480 postmenopausal women and reported a $49 \%$ decreased risk of nuclear opacities in oestrogen users. Studies using tissue culture and animal models also suggest the beneficial effects of oestrogen in lens. Oestrogen protects the lens against TGF- $\beta$ induced cataract in the lens culture system. ${ }^{5}$ Oestrogen has also been reported to exert protective effects in the rat model of age-related cataracts induced by methyl nitrosourea (MNU). ${ }^{6}$

Oxidative stress is widely recognized as one of the major causes of cataract. An elevated level of hydrogen peroxide $\mathrm{H}_{2} \mathrm{O}_{2}$ in the aqueous 
humour and whole lenses has been associated with cataractogenesis. Oxidative stress causes profound injury to a number of intracellular macromolecules in eukaryotic cells, including lipid peroxidation, protein alterations, breakage of covalent bonds of carbohydrates, and cleavage of DNA. The conventional intracellular antioxidant enzymes are overburdened under the oxidative insult. The protection provided by oestrogen against oxidative stress in neuronal tissues has been well documented. ${ }^{7}$ The antioxidative property of oestrogen has been attributed to the phenolic ring, which binds to $\mathrm{H}_{2} \mathrm{O}_{2}{ }^{8}$ The precise mechanism of these cytoprotective effects of oestrogen against $\mathrm{H}_{2} \mathrm{O}_{2}$ in lens epithelial cells (LECs) is not known, but a plethora of cellular responses to the steroid has been reported, including the protection of the mitochondrial function, stimulation of antiapoptotic proteins, and stimulation of protective signalling pathways. ${ }^{9-11}$ Wang et $a l^{12}$ have demonstrated that oestrogens are potent cytoprotectants that preserve the mitochondrial function during $\mathrm{H}_{2} \mathrm{O}_{2}$-induced oxidant insult. Nevertheless, the exact mechanism of oestrogen action against oxidative stress is not known. Moreover, it is not clear how oestrogen modulates the antioxidative defense system in response to the oxidative insult, and the precise time for its antioxidative action in the visual system is not known.

In this study, we tested the interim protective effects of oestrogens against oxidative stress using in vitro human cultured LECs. The ability of oestrogen to modulate the adverse effects of $\mathrm{H}_{2} \mathrm{O}_{2}$ by stopping the cells sensing the stress signal is elucidated in this study.

\section{Materials and methods}

The research followed the tenets of the declaration of Helsinki and the institutional ethical review board.

\section{Chemicals and biochemicals}

All the routinely used chemicals, including culture media, were obtained from Sigma (St Louis, MO, USA). Fetal calf serum was obtained from Hyclone Laboratories (UT, USA). $\mathrm{H}_{2} \mathrm{O}_{2}$ and tetraethoxypropane was obtained from Merck India Ltd.(Mumbai, India). All chemicals were of reagent grade quality.

\section{Primary culture of human LECS}

Circular pieces of cataractous human anterior lens capsule (rhexis), about $6 \mathrm{~mm}$ in diameter, were obtained postoperatively in sterile normal saline. The cataract type was recorded using the slit lamp according to the zone of opacification. The grading of nuclei based on the degree of hardness was performed according to the
Emery-Little classification. All the anterior capsules belonged to a mixed cataract type (nuclear + cortical), with 2-3 grades from male or female patients of the same age group (50-65 years).

A single rhexis was placed in Eagle's minimal essential medium (MEM) containing $10 \%$ fetal calf serum in a single well of 24-well plate and incubated in a $5 \% \mathrm{CO}_{2}$ incubator at $37^{\circ} \mathrm{C}$. The rhexis was allowed to attach itself to the wall of the plate followed by acclimatization of the LECs for $48 \mathrm{~h}$ in the culture medium. This primary culture of LECs was used for all further experiments. Each anterior capsule was used for development of one primary culture for $48 \mathrm{~h}$ after which cells were given respective treatments with $\mathrm{H}_{2} \mathrm{O}_{2}$ or oestrogen as mentioned. The biochemical property of the LECs in culture was analysed by measuring the catalase activity at various time periods as described later. A total of 188 anterior capsules were used for the development of primary cultures for this study.

\section{$\mathrm{H}_{2} \mathrm{O}_{2}$ treatment}

The LECs in the primary culture were exposed to oxidative stress conditions by the addition of $\mathrm{H}_{2} \mathrm{O}_{2}$ to a final concentration of $5 \mu \mathrm{M}$ in the culture medium. In the preliminary experiments, concentrations of 50 and $100 \mu \mathrm{M} \mathrm{H}_{2} \mathrm{O}_{2}$ were also used to decide the toxic and subtoxic doses of $\mathrm{H}_{2} \mathrm{O}_{2}$. Catalase was measured to study the effect of $\mathrm{H}_{2} \mathrm{O}_{2}$ on the LECs at various points of time. The $\mathrm{H}_{2} \mathrm{O}_{2}$ concentration of $5 \mu \mathrm{M}$ was found to induce apoptosis and minimum necrosis, and hence was used for all further experiments.

\section{Oestradiol treatment}

A total of $17 \beta$-oestradiol was added at a concentration of $5 \times 10^{-8} \mathrm{M}$ to the culture medium either before, during or after $\mathrm{H}_{2} \mathrm{O}_{2}$ treatment at various points of time as mentioned. After each treatment, the catalase and peroxidase activity, viable count, lipid peroxidation, total antioxidant status TAS, and DNA damage in the LECs were determined as described later. Morphological changes were observed under an inverted microscope at $\times 40$ magnification.

\section{The trypan blue exclusion method for cell viability}

The viable count of cells was carried out through the vital staining method using trypan blue stain. Trypan blue is a dye that cannot enter cells through an intact membrane, and therefore stains only those cells that are undergoing membrane disruption. The cells were then washed twice with PBS and stained with $0.025 \%$ trypan blue in PBS for $3 \mathrm{~min}$. Blue cells were then counted and these counts 
were used to calculate the relative proportion of the dead cells.

\section{Catalase assay}

Catalase activity was assayed using Luck's method. ${ }^{13}$ The enzyme extract was prepared by homogenizing the cells in a lysis buffer $(0.25 \mathrm{M}$ sucrose, $20 \mathrm{mM}$ tris- $\mathrm{HCl}$, $100 \mathrm{mM} \mathrm{KCl}, 40 \mathrm{mM} \mathrm{NaCl}$, and $10 \mathrm{mM} \mathrm{MgCl} 2$ ), centrifuging them at $20000 \mathrm{~g}$ for $30 \mathrm{~min}$ at $4{ }^{\circ} \mathrm{C}$, and re-extracting the pellet in a microsomal dilution buffer $\left(0.1 \mathrm{M} \mathrm{KH}_{2} \mathrm{PO}_{4}, 20 \%\right.$ glycerol, $10 \mathrm{mM}$ EDTA, and $0.1 \mathrm{mM}$ $\beta$-mercaptoethanol). The pooled extract was added to $10 \mathrm{mM} \mathrm{H}_{2} \mathrm{O}_{2}$, and the rate of decomposition of $\mathrm{H}_{2} \mathrm{O}_{2}$ was measured spectophotometrically at $240 \mathrm{~nm}$. Decomposition of $1 \mu \mathrm{M} \mathrm{H}_{2} \mathrm{O}_{2}$ in 1 min corresponds to $1 \mathrm{U}$ of catalase.

\section{Lipid peroxidation}

The extent of lipid peroxidation was examined by the thiobarbituric acid-reactive substances, such as malondialdehyde TBARS assay, as described by Fujiwara et al. ${ }^{14}$ Cells were homogenized in distiled water and centrifuged at $12000 \mathrm{~g}$, at $4^{\circ} \mathrm{C}$ for $30 \mathrm{~min}$. Aliquots of this homogenate or standards ( $1 \mathrm{mM}$ tetraethoxypropane in $0.01 \mathrm{~N} \mathrm{HCl}$ ) were combined with $1 \mathrm{ml} 29 \mathrm{nM}$ 2thiobarbituric acid (in $8.75 \mathrm{M}$ acetic acid) followed by placing in a water bath at $95^{\circ} \mathrm{C}$ for $1 \mathrm{~h}$ and cooling under a water tap. A unit of $5 \mu \mathrm{l}$ of $5 \mathrm{M} \mathrm{HCl}$ and $3.5 \mathrm{ml}$ butanol were added to the aliquots, after which the tubes were agitated for $5 \mathrm{~min}$ and centrifuged in a table top centrifuge to facilitate separation of layers. The upper butanol phase was then removed and the absorbance was quantified at $525 \mathrm{~nm}$. The TBARS or malondialdehyde levels were calculated from the standard graph and expressed as $\mathrm{nmol} / \mathrm{mg}$ of protein.

\section{Total antioxidant activity assay}

The ABTS- $\mathrm{H}_{2} \mathrm{O}_{2}$-HRP assay system as described by Chen et $a l^{15}$ was used to determine the antioxidant status. The ABTS- $\mathrm{H}_{2} \mathrm{O}_{2}-\mathrm{HRP}$ assay system measures the total antioxidant activity. In principle, when ABTS (2,2-azino-bis93-ethylbenthiazoline-6-sulfonic acid) is incubated with peroxidase and $\mathrm{H}_{2} \mathrm{O}_{2}$, the relatively longlived cation $\mathrm{ABTS}^{+}$is formed which is green in colour. In the presence of antioxidant reductant and hydrogen donors, the radical cation is quenched and green colour formation is delayed. This lag time is proportional to the total antioxidant activity in the sample. The wet weight of the rhexis was taken using a mettler weighing machine followed by homogenization in $6 \%$ orthophosphoric acid with $1 \mu \mathrm{M}$ EDTA and centrifugation at $4^{\circ} \mathrm{C}, 12000 \mathrm{~g}$. The working solution contained $2.0 \mathrm{mM}$ ABTS and $0.86 \mathrm{nM}$ horseradish peroxidase HRP in $50 \mathrm{mM}$ phosphate buffer pH7.0. In the cuvette, $240 \mu \mathrm{l}$ of working solution, $10 \mu \mathrm{l}$ of sample homogenate, and finally $25 \mu \mathrm{l}$ of $1 \mathrm{mM} \mathrm{H}_{2} \mathrm{O}_{2}$ in $50 \mathrm{mM}$ phosphate buffer was added to initiate the reaction, and readings were taken immediately at $414 \mathrm{~nm}$. The time taken for the formation of the green ABTS radical formation was calculated. A standard curve was plotted with different concentrations of L-ascorbic acid and the measurement expressed in mg L-ascorbic acid equivalent to per microgram of tissue.

\section{Comet assay for DNA damage}

After the respective treatments, the cells were harvested and washed with PBS and proceeded for comet assay. The comet assay was performed as described by Singh et al. ${ }^{16}$ Slides were prepared by coating two layers of $1 \%$ high melting point agarose and two layers of low melting point agarose of which one contained cells. The cells were lysed by placing the slides in an alkaline buffer followed by electrophoresis in the same buffer for $20 \mathrm{~min}$. After neutralization, in $0.4 \mathrm{M}$ Tris base $\mathrm{pH} 7.5$, they were stained with $0.01 \%$ Yo-Pro for $5 \mathrm{~min}$ and observed under a florescent microscope. The percentage of cells with comets was calculated. On the basis of their tail lengths, the comets were classified as: score 0, healthy undamaged cells with absence of tail (Normal); score1, small comet $26-50 \mu \mathrm{M}$; score 2, medium comet $51-75 \mu \mathrm{M}$; and score 3 , large comet $>76 \mu \mathrm{M}$.

\section{Protein estimation}

Protein estimation was performed by the eosin Y method as described by Waheed and Gupta. ${ }^{17}$

\section{Statistical analysis}

Statistical analysis was performed using the KruskalWallis (ANOVA) test. The difference between the groups was found by Bonferroni contrast.

\section{Results}

\section{Effect of $\mathrm{H}_{2} \mathrm{O}_{2}$ on LECS}

After the capsule was placed in the culture medium, it was allowed to get acclimatized for $48 \mathrm{~h}$, after which it was attached to the plate; cells with distinct nuclei were seen. The acclimatization period of $48 \mathrm{~h}$ was standardized by measuring the catalase activity at regular time points after placing the rhexis in the media. After placing the cataractous epithelium in the culture medium, a continuous decrease was observed till $48 \mathrm{~h}$ followed by no further decrease in activity until $72 \mathrm{~h}$ (data not shown). Morphologically, after $48 \mathrm{~h}$ of primary 
culture, the capsule was attached to the plate and cells were seen with distinct nucleus with stable catalase activity, and hence used for further experiments.

The exposure of the LECs to $\mathrm{H}_{2} \mathrm{O}_{2}$ for various points of time caused an increase in the catalase activity (Figure 1). Within $6 \mathrm{~h}$ of administration, $5 \mu \mathrm{M} \mathrm{H}_{2} \mathrm{O}_{2}$ initiated a linear increase in catalase activity in the control cells. A sharp decrease in catalase activity was recorded between the

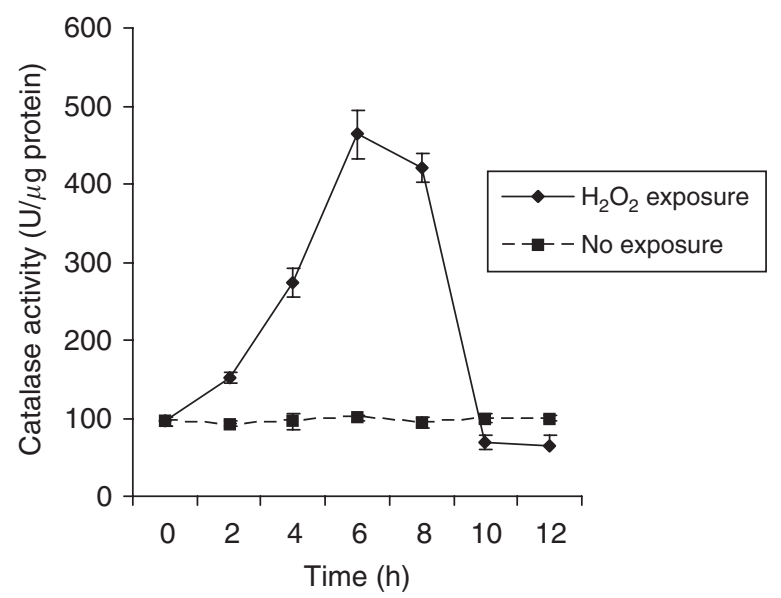

Figure 1 Effect of $\mathrm{H}_{2} \mathrm{O}_{2}$ on catalase activity in cultured LECs. Time course of the effects of $\mathrm{H}_{2} \mathrm{O}_{2}$ on catalase activity in LECs. Increase in catalase activity was seen after $6 \mathrm{~h}$ of $\mathrm{H}_{2} \mathrm{O}_{2}$ administration. Data were computed after three experiments and expressed as mean $\pm \mathrm{SD}$. When SD bars are not shown, they are obscured by the symbol.
8 and $10 \mathrm{~h}$ of $\mathrm{H}_{2} \mathrm{O}_{2}$ administration, after which no further decrease was observed for $24 \mathrm{~h}$.

\section{Effect of 17ß-oestradiol}

To test whether $17 \beta$-oestradiol protects the cells against the $\mathrm{H}_{2} \mathrm{O}_{2}$ effect, the LECs were treated with $5 \times 10^{-9} \mathrm{M}$ $17 \beta$-oestradiol before, simultaneously, and after the $\mathrm{H}_{2} \mathrm{O}_{2}$ exposure. As seen in Figure 2, no increase in catalase activity was observed when the LECs were given $3 \mathrm{~min}$ of oestradiol treatment before $\mathrm{H}_{2} \mathrm{O}_{2}$ exposure. However, simultaneous and post-treatment of oestradiol followed by $\mathrm{H}_{2} \mathrm{O}_{2}$ treatment showed high catalase activity. The $3 \mathrm{~min}$ preincubation period with oestradiol $5 \times 10^{-9}$ was decided on after experimenting with a series of time periods (Figure 3). When the LECs were treated for 1 or $2 \mathrm{~min}$, there was a slight increase in catalase activity, but the difference was not statistically significant $(P$-value $=1)$ when compared to the $\mathrm{H}_{2} \mathrm{O}_{2}$ treated group, whereas treatment for $3 \mathrm{~min}$ and more showed no increase in catalase activity in $\mathrm{H}_{2} \mathrm{O}_{2}$-treated cells and was statistically significant. A slight increase in catalase activity was seen when the LECs were treated only with $17 \beta$-oestradiol; however, the increase was not statistically significant when compared to the cultured LECs. Thus, when the LECs were pretreated with oestradiol for $3 \mathrm{~min}$, the oestradiol was found to nullify the effect of $\mathrm{H}_{2} \mathrm{O}_{2}$. Subsequently, the effectiveness of oestradiol on other stress parameters like viability, lipid peroxidation, total antioxidant status TAS, and DNA damage were

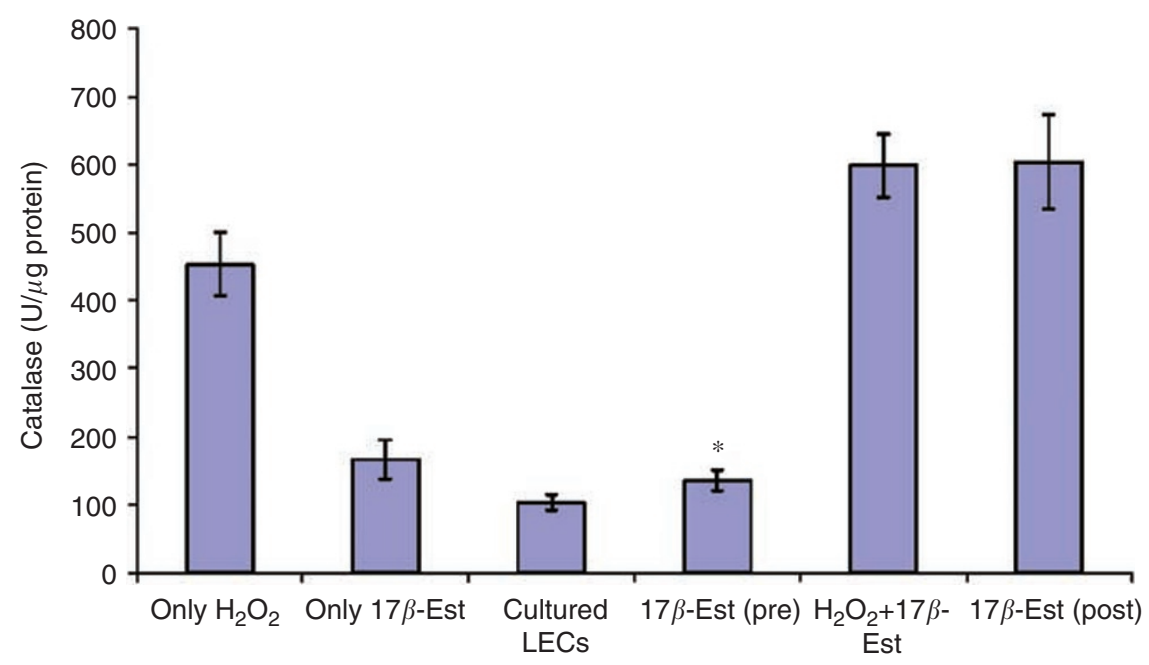

Figure 2 Effect of $17 \beta$-oestradiol against $\mathrm{H}_{2} \mathrm{O}_{2}$ exposure for $6 \mathrm{~h}$ in cultured LECs. Catalase activity was measured in the LECs after three sets of treatment viz oestradiol pretreatment for 3 min of oestradiol pre, simultaneous treatment $\mathrm{H}_{2} \mathrm{O}_{2}+$ oestradiol, and posttreatment (oestradiol post) along with $\mathrm{H}_{2} \mathrm{O}_{2}$ exposure. The three sets of control were primary cultured LECs without any treatment, only oestradiol-treated cultured LECs, and only $\mathrm{H}_{2} \mathrm{O}_{2}$-treated LECs. Of the oestradiol treated sets, only pretreated LECs showed no increase in catalase activity, whereas both the other treatments showed high catalase activity after $\mathrm{H}_{2} \mathrm{O}_{2}$ exposure. The data represented are the average of the three experiments and expressed as Mean $\pm S D, * P<0.005$, significantly different from only $\mathrm{H}_{2} \mathrm{O}_{2}$ treatment. 


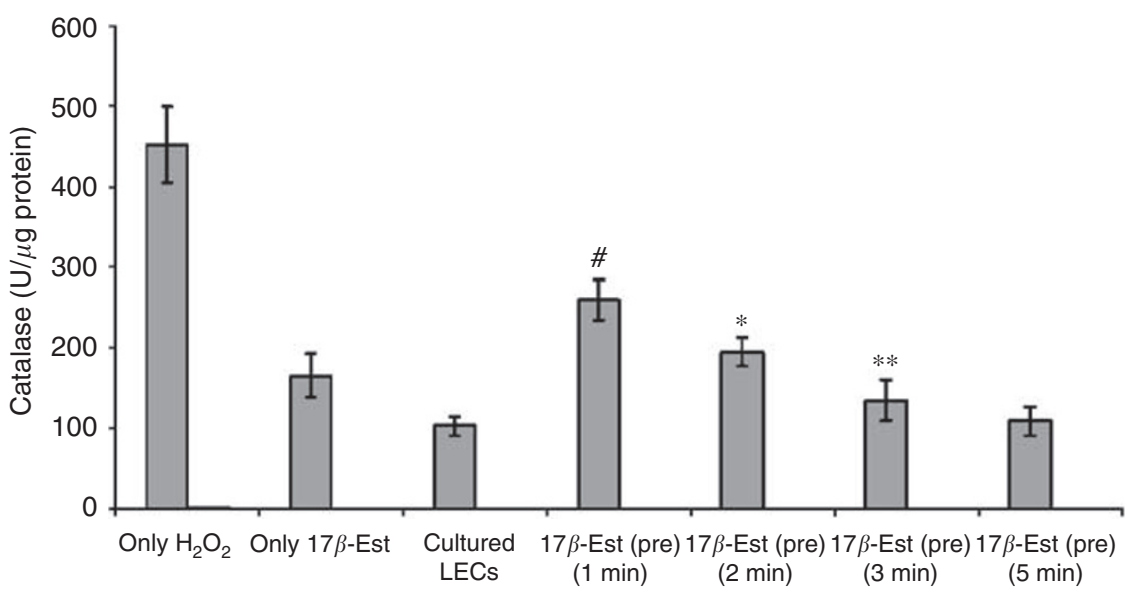

Figure 3 Catalase activity in LECs pretreated with $17 \beta$-oestradiol for various time periods followed by $\mathrm{H}_{2} \mathrm{O}_{2}$ exposure for 6 h. Three-min pretreatment and more showed no increase in catalase activity. Data shown are the average of three experiments. ${ }^{\#} P=1,{ }^{*} P<0.01,{ }^{* *} P<0.001$, significantly different from only $\mathrm{H}_{2} \mathrm{O}_{2}$ treatment.

Table 1 Catalase activity, lipid peroxidation, TAS, and cell viability after pretreatment with $17 \beta$-estradiol for 3 min followed by $\mathrm{H}_{2} \mathrm{O}_{2}$ treatment

\begin{tabular}{lcccc}
\hline Treatments & Control $^{\text {a }}$ & Control $+\mathrm{H}_{2} \mathrm{O}_{2}$ & Control + oestradiol & Control + oestradiol $+\mathrm{H}_{2} \mathrm{O}_{2}$ \\
\hline Catalase (U/ $\mu$ g of protein) & $97.124 \pm 9.4$ & $407.03 \pm 89.11$ & $198.00 \pm 83.64$ & $120.32 \pm 43.52$ \\
Lipid peroxidation (nm/mg protein) & $4.65 \pm 1.37$ & $11.73 \pm 3.60$ & $9.66 \pm 3.94$ & $11.66 \pm 3.48$ \\
Total antioxidant status & $0.17 \pm 0.07$ & $0.35 \pm 0.05$ & $0.13 \pm 0.06$ & $0.12 \pm 0.07$ \\
$(\mu \mathrm{g} / \mathrm{mg}$ wet weight of sample) & $84.27 \pm 6.5$ & $46.85 \pm 5.5$ & $70.31 \pm 1.5$ & $67.32 \pm 5.01$ \\
Viability \% & &
\end{tabular}

Values represent $n=5$ mean \pm SEM.

aPrimary cultured LECs for $48 \mathrm{~h}$.

evaluated. Oestradiol prevented LEC loss due to $\mathrm{H}_{2} \mathrm{O}_{2}$ toxicity. $\mathrm{H}_{2} \mathrm{O}_{2}$ treatment of LECs resulted in a $55.59 \%$ decline in cell survival. A $3 \mathrm{~min}$ preincubation period with oestradiol before $\mathrm{H}_{2} \mathrm{O}_{2}$ treatment increased the cell survival to $79.88 \%$ (Table 1). The TAS of LECs treated with oestradiol before the $\mathrm{H}_{2} \mathrm{O}_{2}$ treatment was two times lower than those treated only with $\mathrm{H}_{2} \mathrm{O}_{2}$. However, oestradiol did not seem to alter lipid peroxidation in LECs as compared to the control LECs. To determine the effect of oestradiol on DNA damage, a comet assay was performed. Figure 4 demonstrates the highest percentage of DNA-damaged cells in $\mathrm{H}_{2} \mathrm{O}_{2}$-treated LECs, whereas the lowest number of the same was seen in oestradioltreated cultured LECs.

\section{Discussion}

The indication of the eye as a target organ for genderspecific hormones has been well documented over the years. ${ }^{1,18}$ The protective role of oestrogen in cataractogenesis has been well studied in in vivo and in vitro conditions. ${ }^{5,6,12,15}$ This study elucidates the quick protective role of $17 \beta$-oestradiol against $\mathrm{H}_{2} \mathrm{O}_{2}$-induced oxidative stress in cultured LECs.

Oxidative insult to the LECs is generated by the elevated $\mathrm{H}_{2} \mathrm{O}_{2}$ concentrations in the aqueous humour during cataractogenesis, and to cope with this oxidative stress, the enzyme activities get elevated as evidenced by the high catalase activity in cultured LECs exposed to $\mathrm{H}_{2} \mathrm{O}_{2}$ as compared to only cultured LECs in this study.

The effect of $\mathrm{H}_{2} \mathrm{O}_{2}$ on cultured human LECs (HLEB3 cell line) was studied by Xing and Lou. ${ }^{19}$ The authors observed no $\mathrm{H}_{2} \mathrm{O}_{2}$-induced DNA damage in cells exposed either to $0.5 \mathrm{mM}$ for $3 \mathrm{~h}$ or $0.05 \mathrm{mM}$ for $72 \mathrm{~h}$, and upon enzymatic analysis, GPx showed $80 \%$ loss in activity. On the contrary, Kleiman et al ${ }^{20}$ found that $\mathrm{H}_{2} \mathrm{O}_{2}$ at concentration as low as $25 \mu \mathrm{M}$ induced DNA damage within $5 \mathrm{~min}$ in bovine LECs. In this study, low concentration $(5 \mu \mathrm{M})$ of $\mathrm{H}_{2} \mathrm{O}_{2}$ also caused apoptosis and induced catalase activity. The discrepancy in the results in all these studies are difficult to explain other than perhaps that the cells come from different origin (viz, primary bovine cells and human transfected cell lines as against primary culture of cataractous LECs used in this study) and in different conditions. Moreover, most of the 


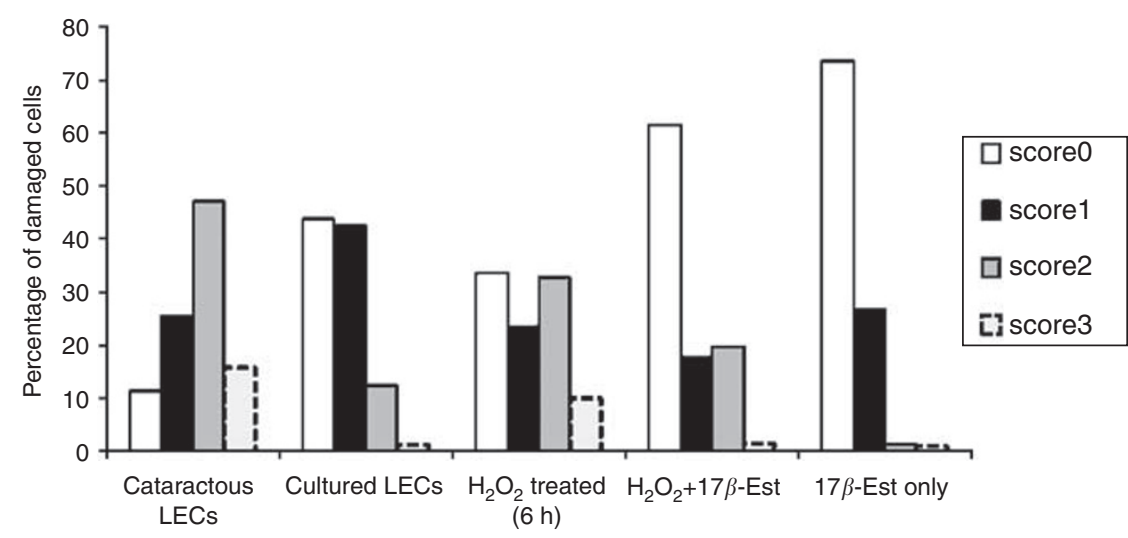

Figure 4 Effect of oestradiol pretreatment on DNA damage caused by $\mathrm{H}_{2} \mathrm{O}_{2}$ in the LECs. LECs were treated with oestradiol for 3 min followed by $\mathrm{H}_{2} \mathrm{O}_{2}$ treatment for $6 \mathrm{~h}$ and they were processed for the comet assay and scored for various classes of DNA damage. Three hundred cells were scored for each treatment and the percentage of damaged cells was calculated. Score 0 represents healthy undamaged cells and scores 1, 2 and 3 represent small, medium, and large comets, respectively. The highest number of DNA damaged cells was found in $\mathrm{H}_{2} \mathrm{O}_{2}$-treated LECs whereas, oestradiol-treated LECs showed the highest number of healthy cells.

authors used confluent cultures ( 0.8 million), whereas approximately only 5000 cells per well were available for our study. Concentration-dependent effects of $\mathrm{H}_{2} \mathrm{O}_{2}$ on cultured rabbit LECs were studied by Ohguro et al. ${ }^{21}$ Low $(1 \mu \mathrm{M})$ dose of $\mathrm{H}_{2} \mathrm{O}_{2}$ led to proliferation, whereas high $(100 \mu \mathrm{M})$ dose killed the LECs. They showed that the survival of cells is greatly dependent on the initial number of cells seeded in the culture plate. With an initial low $(<5000$ cells per well), the cells were not able to survive $(100 \mu \mathrm{M}) \mathrm{H}_{2} \mathrm{O}_{2}$. Our results corroborate with the above finding as the number of cells per well in this study - the number of cells per well is approximately 5000 - and $100 \mu \mathrm{M} \mathrm{H}_{2} \mathrm{O}_{2}$ is lethal to LECs in our culture conditions (data not shown). Catalase was shown to be induced within $1 \mathrm{~h}$ of $50 \mu \mathrm{M} \mathrm{H}_{2} \mathrm{O}_{2}$ treatment by Goswami et al..$^{22}$ In this study, the time of induction for catalase is higher, probably because of the less concentration of $\mathrm{H}_{2} \mathrm{O}_{2}$ used in our study.

The increase in catalase activity upon $\mathrm{H}_{2} \mathrm{O}_{2}$ treatment was prevented by treating the LECs with $17 \beta$-oestradiol for $3 \mathrm{~min}$ before adding $\mathrm{H}_{2} \mathrm{O}_{2}$. Oestradiol pretreatment was found to prevent the detrimental effect of $\mathrm{H}_{2} \mathrm{O}_{2}$ as it was found to preserve cell viability, TAS, and DNA damage in LECs. Of the three treatments, only pretreatment with oestradiol was protective against $\mathrm{H}_{2} \mathrm{O}_{2}$. LECs, when pretreated with oestradiol for 1 and $2 \mathrm{~min}$, showed little protection against $\mathrm{H}_{2} \mathrm{O}_{2}$ as evidenced by the slight increase in catalase activity. However, a pretreatment with $3 \mathrm{~min}$ showed complete inhibition of the increase in catalase activity even in the presence of $\mathrm{H}_{2} \mathrm{O}_{2}$. This short period of oestradiol treatment was sufficient for the oestradiol molecule to penetrate the target cell. Simultaneous application was not protective, probably because the effect of the peroxide molecule is very spontaneous and it takes very little time to diffuse rapidly through the cell barriers. ${ }^{23}$ Steroid hormones are known to exert their action by classical genomic as well as rapid non-genomic pathways. In genomic mode of action, effect of oestrogen on target tissues are mediated through hormone responsive elements and the entire process requires a few hours to few days,$^{24}$ whereas in non-genomic mode, the action is fast and short lived, and thus does not activate transcription or translation.

Oestrogen has been reported to induce instant actions in various tissues. ${ }^{25}$ In this study, it may be possible that the effect of oestradiol is non-genomic as it requires only 3 min to be protective, but only on the target cells as it does not protect the LECs, when added along with $\mathrm{H}_{2} \mathrm{O}_{2}$. Oestradiol has been previously reported to preserve the mitochondrial function, cell viability, and intracellular ATP levels in cultured human LECs during oxidative stress. ${ }^{12,26}$ Emerging published data suggest that these lipophilic hormones are also able to produce rapid effects within several seconds, which cannot be adequately explained through the classical mechanism. These rapid responses have been observed in several tissues, such as myometrial cells, neurons, endothelium, osteoblasts, granulosa cells, and some breast cancer cell lines. ${ }^{27}$

The activities of superoxide dismutase, catalase, and glutathione peroxidase have been shown to be regulated by hormones, and oestradiol has been shown to increase catalase activity in macrophages..$^{28}$ In this study, when cultured LEC's were treated with oestradiol alone in the absence of $\mathrm{H}_{2} \mathrm{O}_{2}$, a slight increase in catalase activity were observed. The results probably suggest that in presence of $\mathrm{H}_{2} \mathrm{O}_{2}$ oestradiol first functions as antioxidant and involved in binding to $\mathrm{H}_{2} \mathrm{O}_{2}$. In simultaneous application of both oestradiol and $\mathrm{H}_{2} \mathrm{O}_{2}$, probably an additive effect is seen. 
The antioxidant nature of oestradiol has been well documented in neuronal cells. ${ }^{29,30}$ Han et $a l^{31}$ demonstrated that the protective potency of various oestrogens was dependent on the precise structure and $17 \beta$-oestradiol, a phenolic ring oestrogen, acted in a way similar to the antioxidants taurine and vitamin C. Studies by Wang et al $^{12}$ using the oestrogen antagonist, ICI 182780 , conclude the non-involvement of oestrogen receptors in the cytoprotective effects of oestrogen. Cytoprotection by oestradiol with only $3 \mathrm{~min}$ of pretreatment has been elucidated for the first time in our study.

Oestrogens have been shown to be powerful antioxidants, effectively preventing lipid peroxidation. ${ }^{32,33}$ However, in our data, oestradiol has no effect on the lipid peroxidation for some unknown reason. The normal physiological level of oestrogen is $0.5 \mathrm{ng} / \mathrm{ml}$. The levels that we used were slightly above this range that is, $5 \times 10^{-8} \mathrm{M}(13.6 \mathrm{ng} / \mathrm{ml})$ but within safe limits, and would not cause any harmful side effects. In most of the in vitro studies of lipid peroxidation oestradiol concentration of $54 \mu \mathrm{M}$, hundreds of fold higher than normal plasma levels has been used. ${ }^{34,35}$ In a study by Santanam et $a l,{ }^{36}$ the authors support the conclusion that at physiolologic concentrations it is unlikely that oestradiol could reduce LDL oxidation. The association of oestradiol with mitochondria has been recently confirmed by Camarata et $a l,{ }^{9}$ with oestrogen receptors being shown on the mitochondrial membrane. The rapid and non-genomic action of oestrogen against acute oxidative stress has been recently shown by Moor et $a l,{ }^{11}$ wherein oestradiol activates an important antiapoptotic pathway within $15 \mathrm{~min}$ of administration. The protective effect of oestradiol mediated by preventing the LECs from undergoing apoptosis is evident from the comet analysis in this study. The stimulation of antiapoptotic proteins by oestrogen has been reported previously. ${ }^{37}$ This study elucidates the rapid protective role of oestradiol against $\mathrm{H}_{2} \mathrm{O}_{2}$-induced stress. The protective function of oestradiol works by preventing the cells from undergoing cell death. Oestradiol regulates the AOD enzymes indirectly by neutralizing $\mathrm{H}_{2} \mathrm{O}_{2}$, and thereby providing the cells with a stress-free atmosphere. Thus, the cells do not sense the stress condition with just 3 min of pretreatment with oestradiol and do not induce antioxidative enzymes. Further studies are in progress to evaluate the antioxidative properties of oestradiol.

\section{Acknowledgements}

We thank Dr Harish Padh, Director, BV Patel Pharmaceutical and Educational Research Centre, Ahmedabad, Gujarat, India for his suggestions during the preparation of manuscript.

\section{References}

1 Gupta PD, Johar Sr K, Nagpal K, Vasavada AR. Sex hormone receptors in the human eye. Surv Ophthalmol 2005; 50: 274-284.

2 Klein BE, Klein R, Lee KE. Incidence of age related cataract: the Beaver Dam Eye study. Arch Ophthalmol 1998; 116: 219-225.

3 Leske MC, Wu SY, Nemesure B, Yang L, Hennis A, Barbados Eye Studies Group. Nine-year incidence of lens opacities in the Barbados Eye Studies. Ophthalmology 2004; 111: $483-490$.

4 Weintraub JM, Taylor A, Jacques P, Willett WC, Rosner B, Colditz GA et al. Postmenopausal hormone use and lens opacities. Ophthalmic Epidemiol 2002; 9(3): 179-190.

5 Hales AM, Chamberlain CG, Murphy CR, McAvoy JW. Estrogen protects lenses against cataract induced by transforming growth factor beta TGFbeta. J Exp Med 1997; 185: 273-280.

6 Bigsby RM, Cardenas H, Caperwell Grant A, Grubbs CJ. Protective effects of estrogen in a rat model of age related cataracts. Proc Natl Acad Sci USA 1999; 96: 9328-9332.

7 Prokai L, Oon SM, Prokai-Tatrai K, Abboud KA, Simpkins JW. Synthesis and biological evaluation of 17betaalkoxyestra-1, 3, 5(10)-trienes as potential neuroprotectants against oxidative stress. J Med Chem 2001; 44(1): 110-114.

8 Manthey D, Behl C. From structural biochemistry to expression profiling: neuroprotective activities of estrogen. Neuroscience 2006; 138(3): 845-850.

9 Cammarata PR, Flynn J, Gottipati S, Chu S, Dimitrijevich S, Younes $\mathrm{M}$ et al. Differential expression and comparative subcellular localization of estrogen receptor beta isoforms of virally transformed and normal cultured human lens epithelial cells. Exp Eye Res 2005; 81: 165-175.

10 Wise PM, Dubai DB, Wilson ME, Rau SW, Bottner M. Neuroprotective effects of estrogen new insights into mechanisms of action. Endocrinology 2001; 142: 969-973.

11 Moore AN, Flynn JM, Gottipati S, Giblin FJ, Cammarata PR. $17-\beta$ estradiol stimulates MAPK signaling pathway in human lens epithelial cell cultures preventing collapse of mitochondrial membrane potential during acute oxidative stress. Mitochondrion 2005; 5: 235-247.

12 Wang X, Simpkins JW, Dykens JA, Cammarata PR. Oxidative damage to human lens epithelial cells in culture: estrogen protection of mitochondrial potential, ATP and cell viability. Invest Ophthalmol Vis Sci 2003; 44: 2067-2075.

13 Luck H. Catalase. In: Bergmaier HU (ed). Methods of Enzymatic Analysis. Verlag Chemie Academic Press: Weinheim, 1963, pp 885-888.

14 Fujiwara K, Sato H, Bannai S. Involvement of endotoxins or tumor necrosis factor-alpha in macrophage mediated oxidation of low-density lipoprotein. FEBS Lett 1998; 431: 116-120.

15 Chen IC, Chang HC, Yang HW, Chen GL. Evaluation of total antioxidant activity of several popular vegetable and Chinese herbs: a fast approach with ABTS $/ \mathrm{H}_{2} \mathrm{O}_{2} / \mathrm{HRP}$ system in microplates. J Food Drug Anal 2004; 12: 29-33.

16 Singh NP, McCoy MT, Tice RR, Schneider EL. A simple technique for quantification of low levels of DNA damage in individual cells. Exp Cell Res 1988; 175: 184-191.

17 Waheed AA, Gupta PD. Application of an eosin B dye method for estimating a wide range of proteins. J Biochem Biophys Methods 1996; 30: 187-196. 
18 Gupta PD, Kalariya N, Nagpal K, Vasavada AR. Interaction of sex steroid hormones with the eye. Cell Mol Biol 2002; 48 OL379-OL386.

19 Xing KY, Lou MF. Effect of $\mathrm{H}(2) \mathrm{O}(2)$ on human lens epithelial cells and the possible mechanism for oxidative damage repair by thioltransferase. Exp Eye Res 2002; 74(1): 113-122.

20 Kleiman NJ, Wang RR, Spector A. Hydrogen peroxideinduced DNA damage in bovine lens epithelial cells. Mutat Res 1990; 240(1): 35-45.

21 Ohguro N, Fukuda M, Sasabe T, Tano Y. Concentration dependent effects of hydrogen peroxide on lens epithelial cells. Br J Ophthalmol 1999; 83(9): 1064-1068.

22 Goswami S, Sheets NL, Zavadil J, Chauhan BK, Bottinger $\mathrm{EP}$, Reddy VN et al. Spectrum and range of oxidative stress responses of human lens epithelial cells to $\mathrm{H}_{2} \mathrm{O}_{2}$ insult. Invest Ophthalmol Vis Sci 2003; 44(5): 2084-2093.

23 Halliwell B, Gutteridge JMC. Free Radicals in Biology and Medicine, 3rd edn. Oxford University Press: Oxford, UK, 1999, pp 381-385.

24 Singh S, Gupta PD. Induction of phosphoinositide-mediated signal transduction pathway by 17 beta estradiol in rat vaginal epithelial cells. J Mol Endocrinol 1997; 19: 249-257.

25 Wehling M. Looking beyond the dogma of genomic steroid action: insights and facts of the 1990s. J Mol Med 1995; 73: 439-447.

26 Moore AN, Gottipati S, Maller RT, Sun J, Giblin FJ, Roque R et al. A putative mitochondrial mechanism for antioxidative cytoprotection by 17beta-estradiol. Exp Eye Res 2004; 78: 933-944.

27 Djahansouzi S, Niederacher D, Hanstein B, Dall P, Bender HG. Nongenomic effects of estrogens on signal transduction pathways in estrogen-sensitive carcinoma cell lines. Breast Cancer Res 2001; 3(Suppl 1): A22.

28 Pereira B, Rosa LF, Safi DA, Bechara EJ, Curi R. Hormonal regulation of superoxide dismutase, catalase, and glutathione peroxidase activities in rat macrophages. Biochem Pharmacol 1995; 50(12): 2093-2098.
29 Green PS, Yang SH, Nilsson KR, Kumar AS, Covey DF, Simpkins JW. The nonferminizing enantiomer of 17beta Estradiol exerts protective effects in neuronal cultures and a rat model of cerebral ischemia. Endocrinology 2001; 142: 400-406.

30 Lopez Jaramillo P, Teran E. Improvement in functions of the central nervous system by estrogen therapy might be related with an increased nitric oxide production. Endothelium 1999; 6: 263-266.

31 Han HJ, Park SH, Park HJ, Park KM, Kang JW, Lee JH et al. Effect of various oestrogens on cell injury and alteration of apical transporters induced by tert-butyl hydroperoxide in renal proximal tubule cells. Clin Exp Pharmacol Physiol 2002; 29: 60-67.

32 Ayres S, Tang M, Subbiah MT. Estradiol-17beta as an antioxidant: some distinct features when compared with common fat-soluble antioxidants. J Lab Clin Med 1996; 128(4): 367-375.

33 Tang M, Abplanalp W, Ayres S, Subbiah MT. Superior and distinct antioxidant effects of selected estrogen metabolites on lipid peroxidation. Metabolism 1996; 45(4): 411-414.

34 Rifici VA, Khachadurian AK. The inhibition of low-density lipoprotein oxidation by 17-beta estradiol. Metabolism 1992; 41(10): 1110-1114.

35 Negre-Salvayre A, Pieraggi MT, Mabile L, Salvayre R. Protective effect of 17 beta-estradiol against the cytotoxicity of minimally oxidized LDL to cultured bovine aortic endothelial cells. Atherosclerosis 1993; 99(2): 207-217.

36 Santanam N, Shern-Brewer R, McClatchey R, Castellano PZ, Murphy AA, Voelkel S et al. Estradiol as an antioxidant: incompatible with its physiological concentrations and function. J Lipid Res 1998; 39(11): 2111-2118.

37 Wu TW, Wang JM, Chen S, Brinton RD. 17 Beta-estradiol induced $\mathrm{Ca}^{+}$influx via L-type calcium channels activates the Src/ERK/cyclic-AMP response element binding protein signal pathway and BCL-2 expression in rat hippocampal neurons: a potential initiation mechanism for estrogeninduced neuroprotection. Neuroscience 2005; 135: 59-72. 